\title{
BENTUK PERLINDUNGAN HUKUM TERHADAP KDNSUMEN AKIBAT IKLAN YANG MENYESATKAN PADA MEDIA CETAK
}

\author{
Tulus Siambaton', Yosua Lorenzo Tarigan ${ }^{2}$ \\ Fakultas Hukum Universitas HKBP Nommensen, Medan \\ tulussiambaton国gmail.com'
}

\section{Info Artikel \\ Diterima : 14 Agustus 2020 \\ Revisi : 21 September 2020 \\ Terbit : 18 Desember 2020}

\section{Key wards:}

Advertising, Misleading, Print Media.

\section{Kata Kunci:}

Iklan, Menyesatkan, Media Massa

\section{Corresponding Author :}

Tulus Siambaton, E-mail : tulussiambatan回gmail.com

\begin{abstract}
This study aims to determine the implementation of legal protection for consumers due to misleading print media advertising against misleading advertisements in print media viewed from Law No. 8 of 1999 on Consumer Protection because, in fact there are still consumers who do not know how the legal protection is due to such misleading advertising.

The method used in the writing of this research is the method of library research that collects data by daing library material or secondary data that includes legislation, books, mass media, and other reading related to the writing of this research and field research methods, which is a research process by collecting data related to obtained directly from the field. In this study the collection of data in the form of interviews obtained at the place of pre-determined interviews.

From the results of research obtain the form of legal protection that can be done by consumers due to misleading print media advertising is in the form of the Institution Consumer Protection Society (LPKSM) which has the task of one is to assist consumers in fighting for rights, which is based on the The Consumer Protection of Law in protecting consumers ather than thase officially established by the gavernment, in Chapter IX Article 44 and the accountability of the respective business actors are those responsible for providing compensation for damage, pollution and / or consumer loss resulting from the consumption of gouds and / or services produced or traded under Article 7, Article 19 paragraph (I) and Article 2Q UUPK (The Consumer Protection of Law).
\end{abstract}


dihubungkan dengan Undang-undang Nomor 8 Tahun 1999 tentang Perlindungan Konsumen. Hal ini mengingat kenyataanya masih banyak konsumen yang tidak mengetahui bagaimana perlindungan terhadap akibat iklan yang menyesatkan.

Metode penenelitian yang dilakukan dengan menggunakan tinjauan kepustakaan, mengumpul bahan-bahan literature dan data skunder seperti perundang-undangan, buku-buku, media massa dan bacaan lainyan yang ada hubungannya dengan penelitian ini dengan mengumpulkan data secara langsung dari lapangan dengan menyiapkan format penuntun interview kepada responden.

Hasil penelitian memperlihatkan adanya bentuk perlindungan hukum yang dapat dilakukan dengan memohon kepada Lembaga Perlindungan Hukum Swadaya Masyarakat. Lembaga ini melaksanakan pengawasan bersama pemerintah dan masyarakat terhadp perlindungan knnsumen. memberikan bantuan bagaimana menuntut hak sebagaimana yang disebutkan dalam bab IX pasal 44 UUPK. Dalam pasal 7, pasal 19 dan pasal 20 UUPK memberikan perlindungan kepada konsumen dimana disebutkan pelaku usaha memberikan infarmasi yang benar dan bertanggung jawab atas kerugian yang timbul akibat kerusakan pencemaran dan kerugian akibat mengkonsumsi barang dan atau jasa. Pelaku usaha periklanan bertanggung jawab atas iklan yang diproduksi dan segala akibat yang ditimbulkan oleh iklan tersebut.

\section{PENDAHULUAN}

Perkembangan teknologi dan industri dalam pembangunan dewasa ini memberikan dampak perlunya untuk memikirkan perlindungan konsumen.Hal ini dikarenakan banyak pengusaha ingin mencari keuntungan yang sebesar-besarnya dari teknologi dan industri dalam waktu yang sesingkatnya tanpa memperhatikan kepentingan konsumen,dan hal ini melanggar hak hak konsumen yaitu hak untuk mendapatkan informasi yang benar dan jujur.

Media sebagai salah satu sarana dalam penyampaian informasi mempunyai berbagai jenis seperti media cetak (koran, majalah, tabloid dan lain-lain) dan media elektronik (televisi, radio, dan lain-lain). Media cetak sebagai salah satu media merupakan sarana penyampaian informasi yang sudah memasyarakat. Qleh karena itu, pelaku usaha dalam memasarkan produknya dapat menggunakan media cetak untuk pemasangan iklan.

Salah satu alat yang sering digunakan pelaku usaha untuk memasarkan produk-produknya adalah dengan iklan. Menurut Undang-Undang Nomor 8 tahun 1999 tentang Perlindungan Konsumen, promasi adalah kegiatan pengenalan atau penyebarluasan informasi suatu barang dan/atau jasa, untuk menarik minat beli knnsumen terhadap barang dan/atau jasa yang akan dan sedang diperdagangkan.

Iklan merupakan salah satu bentuk penyampaian informasi mengenai barang dan atau jasa dari pelaku usaha kepada konsumen, maka dari itu iklan tersebut sangat penting kedudukannya bagi pelaku usaha sebagai alat untuk membantu memperkenalkan produk atau jasa yang ditawarkannya kepada konsumen. Tanpa adanya iklan berbagai produk barang dan atau jasa tidak dapat mengalir secara lancar ke para distributor atau penjual, apalagi sampai ke tangan para knnsumen atau pemakainya.

Salah satu asas umum kade etik periklanan yaitu iklan harus jujur, bertanggung jawab dan tidak bertentangan dengan ketentuan hukum yang berlaku. Iklan yang menyesatkan (fraudulent misrepresentation) menurut Kees Bartens dilakukan bukan hanya dengan jalan berbohong melainkan juga dengan jalan tidak mengatakan seluruh kebenaran. Menurut Zaim Saidi menyesatkan/misrepresentation adalah kegiatan yang 
dilakukan oleh iklan dengan dua cara yaitu memakain pernyataan yang jelas-jelas salah (fa/se statement) dan satu lagi dengan menggunakan pernyataan yang menyesatkan (mis/eading statement). Kata misrepresentatian dapat diartikan sebagai pemberian keterangan yang tidak benar atau kekeliruan, sedang kata fraudulent memberikan makna kecurangan.

Iklan media cetak meliputi di surat kabar, majalah, brasur dan poster. Dalam iklan media cetak pihakpihak yang terkait meliputi produsen atau pengiklan, biro iklan, dan media. Pembuatan iklan media cetak melalui beberapa proses atau tahapan yaitu produsen atau pengiklan menyerahkan brief klien yang berisi mengenai infarmasi atau data-data tentang produk berupa merek produk, manfaat, keunggulan, kelemahan, dan target pasar (yang perlu dipertanyakan adalah kebenaran infarmasi dari klien atau pengiklan ini). Selanjutnya brief klien oleh biro iklan dengan strategi kreatifnya diolah kemudian diwujudkan dalam bentuk iklan media cetak (apakah dalam proses kreatif ini melanggar kode etik periklanan), dan proses terakhir adalah pemasangan di media. Infarmasi iklan yang benar dan bertanggungjawab dapat membantu kansumen menetapkan pilihan yang tepat artinya sesuai kebutuhan dan kemampuannya. Cara pemasaran yang wajar akan mendukung putusan pilihan konsumen yang menguntungkannya.

Salah satu contoh iklan di media cetak yang menyesatkan adalah di salah satu iklan media cetak Koran Analisa Medan yang menerbitkan iklan lowongan pekerjaan oleh perusahaan bernama PT TCL yang beralamat sekarang Jalan Bajak II Simpang Marindal Depan gereja GKPS No.55B yang memerlukan beberapa tenaga kerja pada bagian Supervisior, Suryetor, Administrasi, Staf Gudang, Office Bay, Teknisi, Engineering, Marketing, Koordinator Lapangan, dan Mekanik dengan syarat :

1. Pendidikan SMA, Sederajat, DI, DZ, D3, SI semua jurusan

2. Fotocopy ijazah,

3. Fotocapy KTP,

4. Pas foto $3 \times 4=3$ lembar,

5. Daftar riwayat hidup,

6. Pengalaman tidak diutamakan

7. Disediakan mess, reward, intensive, dan bonus serta seminar leadership

Sebenarnya iklan ini sudah ada sejak 3 tahun lalu yang merugian pemohon akibat iklan yang menyesatkan tersebut. Di iklan disebutkan bahwa perusahaan menerima pegawai yang ditempatkan pada posisi masing masing tetapi kenyataannya di lapangan berbeda. Sewaktu pemohon melamar kerja di Perusahaan yang dulu beralamat Jalan Gatot Subroto Depan Universitas Panca Budi, dimanan pemohon tidak di-interview layaknya penerimaan formal pekerja lainnya akan tetapi dikenalkan langsung kepada yang mengaku pemilik perusahaan tersebut. Setelah itu pemnohon dan pelamar kerja lainnya diberitahukan akan mengikuti training/pelatihan selama 3 bulan sebelum ditempatkan pada pasisi masing masing. Pemohon dan pelamar kerja lainnya mengiyakan untuk mengikuti training tersebut. Sebelum training, pemohon sempat berbincang dengan salah satu pekerja yang sudah dan masih training. Beliau berkata bahwa kami harus daor to daor (pintu ke pintu) untuk menawarkan jasa dan barang berupa perbaikan dan service kompor gas dan harus mencapai target dalam seminggu. Keterangan in terasa janggal dengan pekerjaan yang dijanjikan seperti di iklan. Singkat cerita akhirnya diperaleh info kalau training bukan 3 bulan melainkan bisa 7 bulan bahkan lebih apabila tidak mencapai target. 
Dengan begitu iklan tersebut merugikan karena iklan tersebut tidak sesuai dengan kebenaran pekerjaan yang diiklankan.

Perkembangannya periklanan saat ini tidak jarang melampaui batas-batas etika, kewajaran, kepatutan dan rasionalitas, sehingga aspek psikologi konsumenlah yang menjadi target pelaku usaha dalam memasarkan produknya. Dalam persaingan tidak sehat, iklan dapat menjadi sarana yang dapat menyesatkan konsumen. Ditambah dengan sifatnya yang langsung berhadapan dengan masyarakat dengan wujud penonjolan yang berlebihan. Sampai saat ini Indanesia belum memiliki peraturan khusus setingkat undang-undang guna mengatur kegiatan periklanan, akibatnya terjadi pluralisme ketentuan periklanan dalam hukum positif yang berlaku, misalnya diatur didalam Undang-Undang Nomor 8 Tahun 1999 Tentang perlindungan Konsumen, Kitab Undangundang Hukum Perdata, Kitab Undang-Undang Hukum Pidana, Peraturan Pemerintah, dan Peraturan Menteri yang bersifat Administratif. Sehingga menyisakan beberapa permasalahan berkenaan penentuan hak dan kewajiban pelaku usaha periklanan, bentuk-bentuk penyesatan iklan yang dilarang, beban pertanggungjawaban pelaku usaha periklanan, kedudukan Dewan Periklanan Indanesia sebagai badan pengawas iklan, sampai pada sanksi yang dapat dijatukan kepada pelaku usaha akibat melanggar ketentuan tersebut.

Pembuktian lainnya, dapat dilihat dari kasus iklan yang menyesatkan knnsumen dan mengakibatkan konsumen merasa tertipu antara PT. Excelcaminda Pratama Tbk (XL) melawan Jarlyn H.Sinaga yang perkaranya telah diputus oleh Mahkamah Agung dengan No. Perkara DI/Per.Kons/2007. Bahwa pada tanggal 30 Maret 2006, PT. Excelcaminda Pratama Tbk mendistribusikan brosur/iklan yang memuat informasi tentang Program Tarif Ngirit XL Bebas untuk pelanggan. Program tersebut mulai berlaku tanggal I April 2006 hingga 30 Juni 2006. Jarlyn H.Sinaga, yang tertarik dengan program tersebut pada tanggal I April membeli produk PT. Excelcamindo Pratama Tbk. Namun, Pragram Tarif Ngirit XL Bebas tersebut tidak dapat dijalankan oleh Jarlyn H.Sinaga. Karena Merasa Tertipu akhirnya pada tanggal IG April 2006, Jarlyn H.Sinaga membuat pengaduan kansumen kepada Badan Penyelesaian Sengketa Konsumen (BPSK) Medan.'

Penyesatan informasi produk barang dan jasa melalui iklan tidak hanya berpotensi merugikan konsumen secara materiil bahkan lebih jauh dapat membahayakan kesehatan dan mengancam jiwa konsumen, serta menghilangkan kepercayaan konsumen terhadap infarmasi yang disampaikan pelaku usaha. Oleh karena itu, konsumen mempunyai hak untuk meminta pertanggungjawaban pelaku usaha terhadap penyampaian iklan yang menyesatkan tersebut.

Bertitik tolak dengan latar belakang di atas, maka perlu mengangkat masalah ini untuk dipelajari lebih lanjut, oleh karena itu maka perlu diteliti dengan judul : “BENTUK PERLINDUNGAN HUKUM TERHDAP KDNSLMEN AKIBAT IKLAN YANG MENYESATKAN PADA MEDIA CETAK"

\section{HASIL DAN PEMBAHASAN}

\section{Bentuk Perlindungan Hukum Terhadap Konsumen Akibat Iklan Yang Menyesatkan di Media Cetak}

Perlindungan hukum bagi konsumen atas iklan yang menyesatkan dalam Undang-undang Perlindungan Konsumen, yaitu dengan adanya pengaturan dalam Bab III Pasal 4 sampai dengan Pasal 7 mengenai hak-hak dan kewajiban kansumen dan juga hak dan kewajiban pelaku usaha yang telah disebutkan pada bab sebelumnya. Dalam Bab IV merupakan upaya Undang-undang Perlindungan Konsumen untuk melindungi kansumen, yaitu

' www.xl.co.id/Portals/3/.../I009/Prospektus\%20PUT\%20I\%20XL.pdf.Terakhir diakses 31 Maret 2018 Pukul 11:03 WIB 
terdapatnya aturan mengenai larangan-larangan bagi pelaku usaha yang mengiklankan produk laranganlarangan tersebut dapat dilihat dalam Pasal-Pasal 9, 10, 12, I3 dan 17.

Dalam Pasal 20 Undang-undang Perlindungan Konsumen juga diatur mengenai tanggung jawab pelaku usaha periklanan yang telah dijelaskan sebelumnya. Hal ini untuk melindungi konsumen dari pelaku usaha periklanan yang curang. Begitu pula adanya pengaturan mengenai tanggung jawab pelaku usaha yang terdapat dalam Pasal I9 Undang-Undang Perlindungan Konsumen.

Bentuk lainnya untuk melindungi konsumen, yaitu dengan dibentuknya Badan Perlindungan Konsumen Nasional (BPKN) yang diatur pada Bab VIII Undang-undang Perlindungan Konsumen mulai dari Pasal 31 sampai dengan Pasal 43. Salah satu tugas BPKN (Badan Perlindungan Konsumen Nasional) adalah menerima pengaduan tentang perlindungan konsumen dari masyarakat.

Undang-Undang Perlindungan Konsumen dalam melindungi konsumen selain lembaga yang resmi dibentuk oleh pemerintah, dalam Bab IX Pasal 44 memungkinkan di bentuknya Lembaga Perlindungan Konsumen Swadaya Masyarakat (LPKSM). LPKSM ini mempunyai tugas salah satunya adalah membantu konsumen dalam memperjuangkan hak-haknya, termasuk menerima keluhan atau pengaduan dari kansumen seperti YLKI (Yayasan Lembaga Konsumen Indanesia) .

Mengenai penyelesaian sengketa ini diatur dalam Bab X tentang penyelesaian konsumen. Upaya-upaya penyelesaian sengketa dapat ditempuh dengan cara yang terdapat dalam Pasal 45 ayat (2) yaitu penyelesaian sengketa knnsumen dibagi menjadi 2 bagian, yaitu:

a. Penyelesaian sengketa konsumen nan litigasi (di luar pengadilan)

1) Penyelesaian sengketa secara damai oleh para pihak sendiri

2) Penyelesaian sengketa melalui lembaga yang berwenang, yaitu melalui BPSK ( Badan Penyelesaian Sengketa Konsumen ) dengan menggunakan mekanisme melalui konsiliasi, mediasi atau arbitrase

b. Penyelesaian sengketa konsumen melalui proses litigasi ${ }^{2}$

\section{Penyelesaian Sengketan Konsumen Non Litigasi ( Di Luar Pengadilan)}

\section{a. Penyelesaian Sengketa Secara Damai oleh Para Pihak Sendiri}

Penyelesaian sengketa sebagaimana dimaksud pada pasal 45 ayat (2) Undang-Undang Perlindungan Konsumen, tidak menutup kemungkinan dilakukannya penyelesaian secara damai oleh para pihak yang bersengketa yaitu pelaku usaha dan knnsumen, dan sepanjang tidak bertentangan dengan Undang-Undang Perlindungan Konsumen. ${ }^{3}$ Bahkan dalam penjelasan pasal tesebut dikemukakan bahwa pada setiap tahap diusahakan untuk menggunakan penyelesaian damai oleh kedua belah pihak yang bersengketa. Dari penjelasan Pasal 45 Ayat (2) Undang-Undang Perlindungan Konsumen, dapat diketahui bahwa UUPK (Undang-Undang Perlindungan Konsumen), menghendaki agar penyelesaian damai, merupakan upaya hukum yang justru harus terlebih dahulu diusahakan oleh pihak yang bersengketa, sebelum para pihak memilih untuk menyelesaikan sengketa mereka melalui BPSK (Badan Penyelesaian Sengketa Konsumen) atau badan peradilan. ${ }^{4}$

\footnotetext{
${ }^{2}$ Susanti Adi Nugroho, Proses Penyelesaian Sengketa Kansumen ditinjau dari Hukum Acara Serta Kendala Implementasinya, Jakarta : Kencana, 2008, hlm 98

${ }^{3}$ Ahmadi Miru \& Sutarman Yoda, Hukum Perlindungan Kansumen, Jakarta: Persada, 2008, hlm 224

${ }^{4}$ Susanti Adi Nugroha, Lp.Cit, hlm 99 


\section{b. Penyelesaian Sengketa Melalui Badan Penyelesaian Sengketa Konsumen (BPSK)}

Pemerintah membentuk suatu badan baru, yaitu Badan Penyelesaian Sengketa Konsumen (BPSK), untuk penyelesaian sengketa knnsumen di luar pengadilan. Penyelesaian sengketa konsumen di BPSK (Badan Penyelesaian Sengketa Konsumen) diselenggarakan semata-mata untuk mencapai kesepakatan mengenai bentuk dan besarnya ganti kerugian dan/atau mengenai tindakan tertentu untuk menjamin tidak akan terulang lagi kerugian yang diderita oleh konsumen. ${ }^{5}$

Ketentuan Pasal 49 ayat (I) Undang-Undang Perlindungan Konsumen,yang menetapkan pembentukan Badan Penyelesaian Sengketa Konsumen (BPSK) hanya pada Daerah Tingkat II (kabupaten), memperlihatkan maksud pembuat undang-undang bahwa putusan BPSK (Badan Penyelesaian Sengketa Konsumen) sebagai badan penyelesaian sengketa konsumen diluar pengadilan tidak ada upaya banding dan kasasi. ${ }^{6}$

Dengan adanya BPSK (Badan Penyelesaian Sengketa Konsumen) maka penyelesaian sengketa konsumen dapat dilakukan secara cepat, mudah, dan murah. Cepat karena undang-undang menentukan dalam tenggang waktu 21 hari kerja, BPSK (Badan Penyelesaian Sengketa Konsumen) wajib memberikan putusannya. ${ }^{7}$ Mudah karena prosedur administratif dan proses pengambilan putusan sangat sederhana. Murah terletak pada biaya perkara yang terjangkau.

Setiap knnsumen yang merasa dirugikan oleh pelaku usaha dapat mengadukan masalahnya kepada BPSK (Badan Penyelesaian Sengketa Konsumen), baik secara langsung, diwakili kuasanya maupun oleh ahli warisnya. ${ }^{8}$ Pengaduan yang disampaikan oleh kuasanya atau ahli warisnya hanya dapat dilakukan apabila konsumen yang bersangkutan dalam keadaan sakit, meninggal dunia, lanjut usia, belum dewasa atau warga negara asing.

Menurut ketentuan pasal 54 ayat (4), ketentuan teknis dari pelaksanaan tugas majelis BPSK (Badan Penyelesaian Sengketa Konsumen) yang akan menangani dan menyelesaikan sengketa konsumen akan diatur tersendiri aleh Menteri Perindustrian dan Perdagangan. ${ }^{9}$ Dalam pasal 54 ayat (3) Undang-Undang Perlindungan Konsumen dikatakan bahwa putusan yang dijatuhkan majelis BPSK (Badan Penyelesaian Sengketa Konsumen) bersifat final dan mengikat. Walaupun demikian, para pihak yang tidak setuju atas putusan tersebut dapat mengajukan keberatan kepada Pengadilan Negeri untuk diputus. Terhadap putusan Pengadilan Negeri ini, meskipun dikatakan bahwa Undang-Undang Perlindungan Konsumen hanya memberikan hak kepada pihak yang merasa tidak puas atas putusan tersebut untuk mengajukan kasasi ke Mahkamah Agung, namun dengan mengingat akan relativitas dari "tidak merasa puas", peluang untuk mengajukan kasasi sebenarnya terbuka bagi setiap pihak dalam perkara. ${ }^{\text {ID }}$

Suatu penyelesaian sengkta alternatif yang baik setidak-tidaknya haruslah memenuhi prinsip-prinsip sebagai berikut:

a) haruslah efisien dari segi waktu;

b) haruslah hemat biaya;

c) haruslah dapat diakses oleh para pihak,misalnya tempatnya jangan terlalu jauh;

\footnotetext{
5 Ibid, hlm 100

${ }^{6}$ Ahmadi Miru \& Sutarman Yoda, Dp. Cit, hlm 242

7 Undang-Undang No 8 Tahun 1999 tentang Perlindungan Konsumen, Pasal 55

${ }^{8}$ Susanti Adi Nugraho, Lac. Lit

${ }^{9}$ Gunawan Widjaja \& Ahmad Yani, Hukum Tentang Perlindungan Kansumen, Jakarta: Gramedia Pustaka, 2000, hlm 78

10 /bid, hlm 79
} 
d) haruslah melindungi hak-hak dari pihak yang bersengketa;

e) haruslah dapat menghasilkan putusan yang adil dan jujur;

f) badan atau orang yang menyelesaikan sengketa haruslah terpecaya di masyarakat dan para pihak yang bersengketa;

g) putusannya harus bersifat final dan mengikat;

h) putusannya haruslah dapat mudah dieksekusi;

i) putusannya haruslah sesuai dengan perasaan keadilan dari komunitas dimana penyelesaian sengketa dilaksanakan."

Adapun bentuk penyelesaian BPSK (Badan Penyelesaian Sengketa Konsumen) dilakukan dengan cara knnsiliasi, mediasi, arbitrase. Akan tetapi, tata cara penyelenggaraannya diatur tersendiri dalam keputusan menteri perindustrian dan perdagangan. Untuk lebih jelasnya dapat dijelaskan pada bagian selanjutnya.

\section{A. Konsiliasi}

Konsiliasi adalah salah satu lembaga alternatif penyelesaian sengketa sebagaimana disebut dalam Pasal I ayat (I0) Undang-Undang Nomor 30 Tahun $1999 .{ }^{12}$ Konsiliasi permufakatan adalah penyelesaian sengketa dengan cara melalui musyawarah, hakikatnya adalah untuk menghindari proses pengadilan dan akibat-akibat hukum timbul dari suatu putusan pengadilan. ${ }^{13}$

Penyelesaian sengketa ini banyak kesamaan dengan arbitrase, dan juga menyerahkan kepada pihak ketiga untuk memberikan pendapatnya tentang sengketanya yang disampaikan oleh para pihak, walaupun demikian pendapat knnsiliator tidak mengikat sebagaimana putusan arbitrase. ${ }^{14}$

Hasil musyawarah yang merupakan kesepakatan antar-konsumen dan pelaku usaha yang bersengketa selanjutnya dibuat dalam bentuk perjanjian tertulis yang ditandatangani oleh para pihak yang bersengketa, dan diserahkan kepada majelis untuk dituangkan dalam keputusan majelis BPSK (Badan Penyelesaian Sengketa Kansumen) yang menguatkan perjanjian tersebut. ${ }^{15}$

\section{B. Mediasi}

Mediasi adalah proses negosiasi penyelesaian sengketa atau pemecahan masalah dimana pihak-pihak ketiga yang tidak memihak (impartia) bekerjasama dengan para pihak yang bersengketa membantu memperoleh kesepakatan perjanjian yang memuaskan. ${ }^{16}$ Mediasi juga merupakan salah satu alternatif dan cara penyelesaian suatu persengketaan dimana pihak-pihak yang bersengketa menyelesaikan penyelesaiannya kepada searang mediatar dengan maksud untuk memperoleh hasil yang adil dan diterima oleh para pihak yang bersengketa. ${ }^{17}$

Dengan menyetujui pemecahan knflik melalui mediasi, pihak-pihak terkait telah mengurangi menumpuknya beban perkara perkara peradilan sehingga pengadilan dapat lebih mengurusi hal-hal yang penting lainnya. ${ }^{18}$ Mahkamah Agung dengan Perma Nomor 2 Tahun 2003 memakai sistem mediasi, dalam hal ini Pengadilan setelah memanggil pihak-pihak untuk bersidang, kemudian para pihak atau wakilnya datang menghadap, maka Ketua Majelis Hakim wajib menunda persidangan guna menempuh perdamaian dengan para

\footnotetext{
"Susanti Adi Nugroho, Dp.Lit, hlm IDI

${ }_{12}$ Sophar Maru Hutagalung, Praktek Peradilan Perdata dan Alternatif Penyelesaian Sengketa, Jakarta:Sinar Grafika,2012, hlm 314

13 Ibid.

${ }^{14}$ Ahmadi Miru \& Sutarman Yoda, Dp.Cit, hlm 254

15 lbid.

16 /bid, hlm 109

${ }^{17}$ Sophar Maru Hutagalung, Dp.Cit, hlm 322

18 Ibid.
} 
pihak menunjuk mediator, boleh jadi kesepakatan para pihak atau wakilnya untuk menunjuk salah seorang Hakim di Pengadilan atau Panitera / Panitera Pengganti, atau orang lain di luar daftar mediatar yang ada di Pengadilan. ${ }^{19}$

Para mediator sangat terbatas, yaitu pada hakikatnya hanya menolong para pihak untuk mencari untuk mencari jalan keluar dari persengketaan yang mereka hadapi, sehingga hasil penyelesaian dalam bentuk komprami terletak sepenuhnya pada kesepakatan para pihak, dan kekuatannya tidak secara mutlak mengakhiri sengketa secara final dan tidak pula mengikat secara mutlak tapi tergantung pada itikad baik untuk memenuhi secara sukarela. ${ }^{20}$ Kesepakatan dapat dilakukan sebelum timbulnya sengketa, yaitu dengan memasukkan sebagai klausula perjanjian (mediation clause ageement), atau setelah timbul sengketa kemudian para pihak membuat kesepakatan untuk menyerahkan penyelesaiannya melalui mediasi (mediation submission). ${ }^{21}$

Peran majelis BPSK (Badan Penyelesaian Sengketa Konsumen) dalam penyelesaian sengketa konsumen dengan cara mediasi secara deskripsi, meliputi tugas sebagai berikut:

a) memanggil konsumen dan pelaku usaha yang bersengketa

b) memanggil saksi dan saksi ahli apabila diperlukan

c) menyediakan forum bagi konsumen an pelaku usaha yang bersengketa

d) secara aktif mendamaikan kedua belah pihak yang bersengketa

e) secara aktif memberikan saran atau anjuran penyelesaian sengketa konsumen sesuai dengan peraturan perundang-undangan di bidang perlindungan konsumen. ${ }^{22}$

Pentingnya mediasi dalam konteks ini dimaknai bukan sekadar upaya untuk meminimalisir perkaraperkara yang masuk ke Pengadilan, baik itu pada Pengadilan tingkat pertama maupun tingkat banding, sehingga badan peradilan dimaksud terhindar dari adanya timbunan perkara, namun lebih dari itu mediasi dipahami dan diterjemahkan dalam proses penyelesaian sengketa secara menyeluruh dengan penuh kesungguhan untuk mengakhiri suatu sengketa yang tengah berlangsung. ${ }^{23}$

\section{Arbitrase}

Kata arbitrase berasal dari bahasa latin yaitu "arbitrare" yang artinya kekuasaan untuk menyelesaikan sesuatu menurut "kebijaksanaan". Dikaitkannya istilah arbitrase dengan kebijaksanaan seolah-olah memberi petunjuk bahwa majelis arbitrase tidak perlu memperhatikan hukum dalam menyelesaikan sengketa para pihak, tetapi cukup berdasarkan kebijaksanaan. ${ }^{24}$

Arbitrase merupakan cara penyelesaian suatu sengketa perdata diluar peradilan umum yang didasarkan pada perjanjian arbitrase yang dibuat oleh para pihak yang bersengketa. ${ }^{25}$ Menurut Mertakusumo, arbitrase adalah suatu prosedur penyelesaian sengketa di luar pengadilan berdasarkan persetujuan para pihak yang berkepentingan untuk menyerahkan sengketa mereka kepada searang wasit atau arbiter. ${ }^{26}$

Didalam Undang-Undang Nomar 30 Tahun 1999, pengetian arbitrase adalah cara penyelesaian suatu sengketa perdata diluar pengadilan, yang didasarkan pada perjanjian arbitrase yang dibuat secara tertulis oleh

\footnotetext{
19 Ibid, hlm 323

20 Yahya Harahap,Beberapa Tinjauan Mengenai Sistem Peradilan dan Penyelesaian Sengketa,Bandung:Citra Aditya,1997,hlm 194

${ }^{21}$ Ahmad Miru \& Sutarman Yodo, Dp.Cit, hlm 255

${ }^{22}$ Susanti Adi Nugraho.,Dp.Cit, hlm III

${ }^{23}$ Sophar Maru Hutagalung, Dp. Lit, hlm 330

${ }^{24}$ Subekti, Arbitrase Perdagangan,Bandung:Bina Cipta,1981, hlm 1-3

${ }^{25}$ Yahya Harahap, Dp.Lit, hlm 400-401

${ }^{26}$ Sudikno Mertokusumo, Mengenal Hukum, Suatu Pengantar, Yogyakarta:Liberty, 1999, hlm 144
} 
para phak yang bersengketa. ${ }^{27}$ Arbitrase sebagai salah satu lembaga alternatif penyelesaian sengketa, adalah bentuk alternatif paling formal untuk menyelesaikan sengketa sebelum berlitigasi. Dalam proses ini pihak sengketa mengemukakan masalah mereka kepada pihak ketiga yang netral dan memberi wewenang untuk memberi keputusan. ${ }^{28}$

Arbitrase yang diatur dalam undang-undang ini merupakan cara penyelesaian suatu sengketa di luar peradilan umum yang didasarkan atas perjanjian tertulis dari pihak yang bersengketa. Tidak semua sengketa dapat diselesaikan melalui arbitrase, melainkan hanya sengketa mengenai hak yang menurut hukum dikuasai sepenuhnya oleh para pihak yang bersengketa atas dasar kata sepakat mereka. ${ }^{29}$

Penyelesaian sengketa konsumen melalui arbitrase, para pihak memilih arbitar dari anggata BPSK (Badan Penyelesaian Sengketa Konsumen) yang berasal dari unsur pelaku usaha dan konsumen sebagai anggata majelis. Arbitor yang telah dipilih oleh para pihak kemudian memilih arbitar ketiga dari anggata BPSK (Badan Penyelesaian Sengketa Konsumen) yang berasal dari unsur pemerintah sebagai ketua. ${ }^{30}$

Pasal 60 Undang-Undang Arbitrase Nomar 30 Tahun 1999 menyebutkan kalau putusan arbitrase bersifat final dan mempunyai kekuatan hukum tetap yang mengikat para pihak. Tearinya, setelah ada putusan arbitrase tidak ada upaya hukum lain yang bisa diajukan oleh pihak yang kalah dan pihak yang menang tinggal menjalankan eksekusi. Kenyataannya, eksekusi putusan arbitrase tidak semudah membalikkan telapak tangan. Pasal 61 Undang-Undang Arbitrase Nomor 30 Tahun 1999 mengatur kalau eksekusi dilaksanakan berdasarkan perintah Ketua Pengadilan Negeri apabila ada pihak yang tidak melaksanakan putusan arbitrase secara sukarela. Selanjutnya, berdasarkan pasal 62 Undang-Undang Arbitrase Nomor 30 Tahun 1999, Ketua Pengadilan Negeri memeriksa terlebih dahulu dokumen, ruang lingkup, dan kompentensi dari arbitrase yang dipilih. ${ }^{31}$

Artinya, Pengadilan Negeri tidak diperkenankan untuk memeriksa pokok perkaranya lagi. Tugasnya hanya mengijinkan atau menolak eksekusi. Kalau menolak, alasannnya hanya yang secara limitatif ditentukan dalam pasal 62 ayat (2) di antaranya apabila putusan arbitrase melanggar kesusilaan dan ketertiban umum. Terhadap penolakan eksekusi karena alasan sebagaimana diatur pasal 62 ayat (2) tidak ada upaya hukum apapun. Undang-Undang Arbitrase Nomor 30 Tahun 1999 pada bagian penjelasannya tidak mendefinisikan atau membatasi ketertiban umum. Akibatnya, definisi ketertiban umum dijadikan legitimasi bagi salah satu pihak untuk meminta pembatalan eksekusi dari Pengadilan Negeri. ${ }^{32}$

Selanjutnya jika tidak tercapai perdamaian maka persidangan dimulai dengan membacakan isi gugatan konsumen,dan surat jawaban dari pelaku usaha. Ketua majelis BPSK (Badan Penyelesaian Sengketa Konsumen) harus memberikan kesempatan yang sama kepada kedua belah pihak yang bersengketa untuk menjelaskan halhal yang dipersengketakan. ${ }^{33}$

\footnotetext{
${ }^{27}$ Undang-Undang Nomor 30 Tahun 1999 tentang Arbitrase dan Alternatif Penyelesaian Sengketa, Pasal 1

${ }^{28}$ Undang-Undang Nomor 30 Tahun 1999 tentang Arbitrase dan Alternatif Penyelesaian Sengketa, Pasal 4

${ }^{29}$ Aman Sinaga, Makalah "Peran dan Fungsi Badan Penyelesaian Sengketa Kansumen dalam Lpaya Perlindungan

Konsumen",Jakarta:Gramedia,2004, hlm 6

30 Gary Goudpaster \& Felix Dentoeng Soebagjo, Arbitrase di Indonesia Beberapa contoh kasus dan Pelaksanaan dalam praktik,Jakarta :

Ghalia, 1995 , hlm 19

${ }^{31}$ http://www.hukumonline.com/berita/baca/hol1905/arbitrase-pilihan-tanpa-kepastian, diakses hari Kamis 24 Mei 2018 pada pukul 19:30 WIB

32 http://www.hukumonline.com/berita/baca/hol1905/arbitrase-pilihan-tanpa-kepastian, diakses hari Kamis 24 Mei 2018 pada pukul 19:35 WIB

${ }^{33}$ Susanti Adi Nugroho, Dp. Cit, hlm 117
} 


\section{Penyelesaian Sengketa Konsumen Melalui Litigasi}

Dalam Pasal 48 Undang-Undang Perlindungan Konsumen mengatakan bahwa penyelesaian sengketa konsumen melalui pengadilan mengacu pada ketentuan tentang peradilan umum yang berlaku dengan memperhatikan ketentuan dalam Pasal 45. ${ }^{34}$ Putusan yang dijatuhkan Majelis BPSK bersifat final diartikan tidak adanya upaya banding dan kasasi, yang ada keberatan.

Apabila pelaku usaha keberatan atas putusan yang dijatuhkan oleh majelis BPSK (Badan Penyelesaian Sengketa Konsumen), maka ia dapat mengajukan keberatannya itu kepada Pengadilan Negeri. Menurut Pasal 58 Undang-Undang Perlindungan Kansumen dalam jangka waktu 14 hari Pengadilan Negeri yang menerima keberatan pelaku usaha memutus perkara tersebut dalam jangka waktu ZI hari sejak diterimanya keberatan tersebut. ${ }^{35}$

Cara mengajukan gugatan atas pelanggaran yang dilakukan pelaku usaha menurut Pasal 46 ayat (I) UUPK dapat dilakukan oleh: ${ }^{36}$

a. Searang knnsumen yang dirugikan atau ahli warisnya.

b. Sekelompok kansumen yang mempunyai kepentingan yang sama.

c. Lembaga perlindungan konsumen swadaya masyarakat yang memenuhi syarat, yaitu berbentuk badan hukum atau yayasan, yang dalam anggaran dasarnya menyebutkan dengan tegas bahwa tujuan didirikannya arganisasi tersebut adalah untuk kepentingan perlindungan konsumen dan telah melaksanakan kegiatan sesuai dengan anggaran dasarnya;

d. Pemerintah dan/atau instansi terkait apabila barang dan/atau jasa yang dikansumsi atau dimanfaatkan mengakibatkan kerugian materi yang besar dan/atau korban yang tidak sedikit.

Masuknya sengketa konsumen ke Pengadilan Negeri berdasarkan keaktifan salah satu pihak atau para pihak yang bersengketa, dalam hal ini pelaku usaha atau konsumen. ${ }^{37}$ Konsumen dapat berinisiatif mengajukan gugatan wanprestasi atau perbuatan melawan hukum terhadap pelaku usaha atas pelanggaran norma-norma Undang-Undang Perlindungan Konsumen, sebaliknya pelaku usaha tidak diperkenankan menggugat konsumen atau mengajukan gugatan balik dengan merujuk pada pelanggaran konsumen atas norma-norma Undang Undang Perlindungan Konsumen, kecuali menyangkut pelanggaran hak-hak pelaku usaha sebagaimana dimaksud dalam pasal 6 Undang-Undang Perlindugan Konsumen. ${ }^{38}$

Agar Undang-Undang Perlindungan Konsumen ini dapat dipatuhi dan dilaksanakan dengan baik, maka terdapat sanksi-sanksi yang dapat dikenakan pelaku usaha yang melanggar ketentuan ini. Sanksi-sanksi tersebut diatur dalam Bab XIII Undang-Undang Perlindungan Kansumen dimulai dari Pasal 60 sampai dengan Pasal 63

Dari uraian di atas dapat ditarik suatu analisis bahwa dengan adanya Undang-Undang Perlindungan Konsumen ini maka sedikit banyak kansumen dapat terlindungi haknya. Disebutkan dalam Bab IV Undang-Undang Perlindungan Konsumen merupakan salah satu upaya dari undang-undang ini untuk menjangkau perlindungan tersebut. Dengan adanya aturan mengenai larangan bagi pelaku usaha untuk mengiklankan produknya. Dengan

\footnotetext{
34 Undang - Undang Nomor 8 Tahun 1999 tentang Perlindungan Konsumen , Pasal 48

35 Undang - Undang Nomor 8 Tahun 1999 tentang Perlindungan Konsumen , Pasal 58

36 Undang - Undang Nomor 8 Tahun 1999 tentang Perlindungan Konsumen , Pasal 46

${ }^{37}$ Susanti Adi Nugroho,Dp.Cit, hlm 130

38 lbid.
} 
adanya aturan ini maka jelas diketahui pelaku usaha mana yang mengiklankan produknya secara tidak benar atau menyesatkan.

\section{KESIMPULAN}

Bertitik talak dari permasalahan yang telah dikemukakan sebelumnya dan berdasarkan analisa data yang diperoleh, maka dapat diambil kesimpulan bahwa:

Perlindungan hukum yang dapat dilakukan terhadap konsumen akibat iklan media cetak yang menyesatkan adalah dengan di bentuknya Lembaga Perlindungan Konsumen Swadaya Masyarakat (LPKSM) yang mempunyai tugas salah satunya adalah membantu konsumen dalam memperjuangkan hak-haknya, termasuk menerima keluhan atau pengaduan dari konsumen seperti YLKI (Yayasan Lembaga Konsumen Indonesia) yang berdasarkan pada Undang-Undang Perlindungan Konsumen dalam melindungi konsumen selain lembaga yang resmi dibentuk oleh pemerintah, dalam Bab IX Pasal 44. Dan upaya-upaya penyelesaian sengketa yang lain dapat ditempuh dengan cara yang terdapat dalam Pasal 45 ayat (Z) yaitu penyelesaian sengketa konsumen dibagi menjadi 2 bagian yaitu, penyelesaian sengketa konsumen non litigasi (di luar pengadilan) penyelesaian sengketa secara damai oleh para pihak sendiri, penyelesaian sengketa melalui lembaga yang berwenang, yaitu melalui BPSK ( Badan Penyelesaian Sengketa Konsumen ) dengan menggunakan mekanisme melalui konsiliasi, mediasi atau arbitrase dan penyelesaian sengketa konsumen melalui proses litigasi.

\section{DAFTAR PUSTAKA}

\section{A. Buku}

Ahmadi Miru \& Sutarman Yoda, Hukum Perlindungan Kansumen, Jakarta: Persada, 2008 AZ Nasution, Hukum Perlindungan Kansumen : Suatu Pengantar, Jakarta: Daya Widya,1999

Dedi Harianto, Perlindungan Hukum bagi Kansumen terhadap Iklan yang Menyesatkan, Ghalia Indonesia. Bogar. 2010

Departemen Pendidikan Kebudayaan Republik Indanesia, Kamus Besar Bahasa Indanesia, Jakarta: Balai Pustaka,1990

Gary Goudpaster \& Felix Dentoeng Saebagja, Arbitrase Di Indanesia Beberapa Cantah Kasus Dan Pelaksanaan Dalam Praktik, Jakarta : Shalia, 1995

Gunawan Widjaja \& Ahmad Yani, Hukum Tentang Perlindungan Kansumen, Jakarta: Gramedia Pustaka, 2000 H.Zainuddin, Metade Penelitian Hukum, Jakarta: Sinar Grafika,2009 Janus Sidabalak, Hukum Perlindungan Kansumen di Indanesia, Bandung: CitraAditya Bakti, 2006

Maria M Darus Badrusza man, Perlindungan Kansumen Dilihat dari Sudut Perjanjian Baku, Jakarta: Bina Cipta, 1986

Monle Lee \& Carla Jahnsan, Prinsip-Prinsip Pakak Periklanan Dalam Perspektif Glabal, Jakarta: Kencana, 2007

Morissan, M.A., PER/KLANAN Kamunikasi Pemasaran Terpadu, Jakarta : Kencana ,20I0.

Muhammad Jaiz, Dasar - Dasar Periklanan, Graha Ilmu, 2014

Pujiyanto, Iklan Layanan Masyarakat, Yogyakarta : ANDI, 2013

Sidharta, Hukum Perlindungan Kansumen Indanesia, Jakarta: Grasinda,2004

Soerjono Soekanto, Pengantar Penelitian Hukum, Jakarta: Ul Press,1986 
Sophar Maru Hutagalung,S.H.M.H., Praktek Peradilan Perdata dan Alternatif Penyelesaian Sengketa, Jakarta:Sinar Grafika,2012

Subekti, Abitrase Perdagangan, Bandung: Bina Cipta, 1982.

Subekti, Hukum Acara Perdata Indonesia, Bandung: Bina Cipta, 19882.

Sudikno Mertokusumn, Mengenal Hukum, Suatu Pengantar, Yogyakarta:Liberty, 1999

Susanti Adi Nugroho, Prases Penvelesaian Sengketa Kansumen ditinjau dari Hukum Acara Serta Kendala Implementasinya, Jakarta : Kencana, 2008

Tri Kurnia Nurhayati, Kamus Lengk ap Bahasa Indanesia, Eska Media, Jakarta 2005

Ujang Rusdianta, Nuansa Perklanan Karporat, Yogyakarta : Calpulis, 2016

Winner Sitorus, Aspek-aspek Hukum Penyelesaian Sengketa Bisnis International Melalui Mediasi Sebagai Alternatif Penyelesaian Sengketa, Jakarta:U|,|1998

Yahya Harahap, Beberapa Tinjauan Mengenai Sistem Peradilan dan Penyelesaian Sengketa, Bandung:Litra Aditya,1997

\section{A. Makalah}

Aman Sinaga, Makalah "Peran dan Fungsi Badan Penyelesaian Sengketa Konsumen dalam Lpaya Perlindungan Konsumen", Jakarta:Gramedia

\section{B. Peraturan Perundang-Undangan}

Kitab Undang-Undang Hukum Perdata

Peraturan Pemerintah Nomar 69 Tahun 1999 tentang Label dan Iklan Pangan

Peraturan Pemerintah Nomor 81 Tahun 1999 tentang Pengamanan Rokok Bagi Kesehatan

Undang-Undang Nomor 2 Tahun 2004 tentang Penyelesaian Perselisihan Hubungan Industrial

Undang-Undang Nomar 8 Tahun 1999 tentang Perlindungan Konsumen

Undang-Undang Nomor 30 Tahun 1999 tentang Arbitrase dan Alternatif Penyelesaian Sengketa

\section{[. Internet}

http://www.hukumonline.com/berita/baca/holl905/arbitrase-pilihan-tanpa-kepastian/

http://www.hukumtenagakerja.com/perselisihan-hubungan-industrial/penyelesaian-perselisihan-hubungan industrial-melalui-knnsiliasi/

http://www.jurnalhukum.com/hukum-perlindungan-konsumen-di-indonesia

http://maximusblue.blogspot.com/2009//2/iklan-vs-hak-konsumen.html

https://terus-tambah-pengetahuan.blogspot.com/2017/02/pengertian-media-cetak.html www.Xl.co.id/Portals/3/.../I0Q9/Prospektus\%20PUT\% 20|\% 20XL.pdf 